
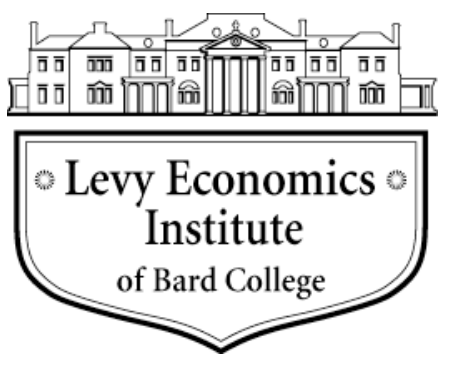

Working Paper No. 744

\title{
Interest Rate Determination in India: Empirical Evidence on Fiscal Deficit - Interest Rate Linkages and Financial Crowding Out
}

by

\author{
Lekha S. Chakraborty* \\ Levy Economics Institute of Bard College
}

December 2012

\begin{abstract}
* The author is a research associate at the Levy Institute and an associate professor at the National Institute of Public Finance and Policy, New Delhi, India. The views expressed in this paper are those of the author and do not necessarily reflect the position of the institutes to which she is affiliated. The author is grateful to M. Govinda Rao for the discussion on interest rate determination, and to Luciano Greco, Pinaki Chakraborty, Sivaramakrishna Sarma, and selected participants of the 68th Congress of the International Institute of Public Finance in Dresden, Germany, August 16-19, 2012, for their comments. Thanks are also due to Amita Manhas for compiling the Reserve Bank of India high-frequency data. The usual disclaimer applies.
\end{abstract}

The Levy Economics Institute Working Paper Collection presents research in progress by Levy Institute scholars and conference participants. The purpose of the series is to disseminate ideas to and elicit comments from academics and professionals.

Levy Economics Institute of Bard College, founded in 1986, is a nonprofit, nonpartisan, independently funded research organization devoted to public service. Through scholarship and economic research it generates viable, effective public policy responses to important economic problems that profoundly affect the quality of life in the United States and abroad.

Levy Economics Institute P.O. Box 5000

Annandale-on-Hudson, NY 12504-5000

http://www.levyinstitute.org

Copyright (C) Levy Economics Institute 2012 All rights reserved 


\begin{abstract}
Controlling for capital flows using the high-frequency macro data of a financially deregulated regime, this paper examines whether there is any evidence of the fiscal deficit determining the interest rate in the context of India. The period of analysis is FY 2006-07 (April) to FY 2011 (April). Contrary to the debates in policy circles, the paper finds that an increase in the fiscal deficit does not cause a rise in interest rates. Using the asymmetric vector autoregressive model, the paper establishes that the interest rate is affected by changes in the reserve currency, expected inflation, and volatility in capital flows, but not by the fiscal deficit. This result has significant policy implications for interest rate determination in India, especially since the central bank has cited the high fiscal deficit as the prime reason for leaving the rates unchanged in all of its recent policy announcements. The paper analyzes both long- and short-term interest rates to determine the occurrence of financial crowding out, and finds that the fiscal deficit does not appear to be causing either shorts and longs. However, a reverse causality is detected, from interest rates to deficits.
\end{abstract}

Keywords: Fiscal Deficit; Asymmetric Vector Autoregressive Model; Financial Crowding Out JEL Classifications: C32, E62, H6 
Theoretically, an analysis of the link between fiscal deficit and interest rate assumes importance mainly for three reasons. First, in the context of the growing global integration of financial markets, the macroeconomic effects of an increase in the domestic interest rate due to the rise in the fiscal deficit can spread globally. Second, if the increase in the fiscal deficit leads to an increase in the interest rate, it may lead to a crowding out of the interest-sensitive components of private spending, especially private corporate investment. And third, if such a relationship is verified, the fiscal and monetary policy linkage in the macro management of a country is established. For instance, a reduction of budget balances could moderate upward pressure on interest rates and could therefore provide monetary policy with additional degrees of freedom in interest rate management. ${ }^{1}$

In the credit policy announcement as recent as July 2012, the Central Bank of India (Reserve bank of India-RBI) kept the interest rates (repo rates) unchanged and advised the government of India's Ministry of Finance to cut the fiscal deficit prior to cutting the interest rates. Keeping interest rates high has detrimental effects on the economic growth of the country. Globally, when central banks have proceeded with the cutting of interest rates, RBI has kept the interest rates unchanged in all recent policy announcements. This invites a compulsory revisiting of the question of whether fiscal deficit affects the interest rate in India. This paper presents a rare examination of the link between the two. Chakraborty (2002) made an attempt to address this empirical link and concludes that a deficit does not induce a rise in the interest rate in India; it is rather the other way around. Two years later, incorporating the monetary variables, the model by Chakraborty (2002) was reexamined by a study from RBI, which found the results consistent with the former (Goyal 2004). These are the two empirical studies on the fiscal deficit and the interest rate exclusively concerning India. Though Chakraborty (2007) revisited the question of crowding out in India, the aspects of the "financial" crowding out channel via the interest rate mechanism was not analyzed in the context of capital flows; rather, the focus of the paper was on "direct" crowding out. However, the study found that fiscal deficit is not a determinant of interest rate in India.

This paper takes the literature forward by incorporating the capital flows in the macro model of interest rate determination. Theoretical literature identifies two variants of crowding

\footnotetext{
${ }^{1}$ In a large number of industrial countries, actual fiscal imbalances prevent monetary policy from properly managing interest rates. Thus, in order to stimulate economic activity, the setting of both monetary and fiscal policies needs to be reassessed within a comprehensive framework of sound and stable fiscal balances over the medium term (CorreiaNunes and Stemitsiotis 1995).
} 
out in an economy: real and financial. ${ }^{2}$ The real crowding out occurs when the increase in public investment displaces private capital formation, which is also termed direct crowding out. ${ }^{3}$ The phenomenon of partial loss of private capital formation in the economy, due to the increase in the interest rates emanating from the preemption of real and financial resources by the government through bond-financing of fiscal deficit, is termed financial crowding out.

Financial crowding out occurs due to the upward pressures on the interest rate induced by the debt financing of fiscal deficit (interest rate effect). The phenomenon of financial crowding out is analyzed in this paper in the context of a deregulated financial regime in India.

The taxonomy of crowding out was discussed in detail by Buiter (1990). According to Buiter, direct crowding out (or crowding in) refers to substitution or complementary relationships between public and private spending that occur not through changes in prices, interest rates, or required rate of return by changes in public sector activity, but through public sector consumption/investment being an argument in private utility functions and through the public sector capital stock being an argument in private sector production functions Buiter (1990, p. 34). Buiter defined indirect crowding out as the consequences of public actions that affect private behavior either by altering budget constraints or by influencing the prices faced by private agents, namely, the interest rate. In other words, crowding out occurring via interest rate changes is referred to as financial crowding out. ${ }^{4}$

\footnotetext{
${ }^{2}$ Blinder and Solow (1973), in their seminal paper, "Does Fiscal Policy Matter," discuss three levels of crowding out at the theoretical level. The first level of crowding out occurs when public investment displaces private investment broadly on a dollar-for-dollar basis. This level of crowding out occurs irrespective of the mode of financing the deficit. The second level of crowding out, as Blinder and Solow (1973) propose, is an integral part of Keynesian tradition. It is based on the notion that deficit spending not accompanied by new issuances of money carries with it the need for government to float debt issues that compete with the private debt instruments in financial markets. The resulting upward pressure on interest rates will reduce any private expenditure, which is interest rate-sensitive. In other words, this financial side effect of crowding out occurs via the interest rate (that is, bond financing of deficit causes market interest rates to rise and, in turn, crowds out private investment). As discussed by Blinder and Solow (1973), there is no theoretical controversy over this second level of crowding out; the only contested issues are empirical. The rationale for a third level of crowding out is that any government deficit requires the issuance of some sort of debt instrument — outside money or interest bearing bonds — and this increase in private wealth will have further reverberations in the economy. In other words, debt financing of deficit simultaneously results in the creation of bonds, which is considered as net wealth in the private sector. It is a matter of debate whether bonds are considered as net wealth in the context of India, and this third level of crowding out may be beyond the scope of the study in the context of India. The second level of crowding out is the focus of this paper.

${ }^{3}$ Real crowding out is important to analyze in the context of developing countries like India because of the large share of public investment in gross capital formation, and moreover, the nature of public investment (whether infrastructure or non-infrastructure) itself can affect private investment differently.

${ }^{4}$ Kotlikoff (1984) also pointed out that "financial crowding out" is advanced in literature through the testing of a causal link between fiscal deficit and interest rate. He further pointed out that much of the concern with "financial crowding out" revolves around the transaction of selling bonds to finance fiscal deficit. As the argument goes, a
} 
Though Chakraborty (2007) established no evidence of direct crowding out of private corporate investment in India, the absence of direct crowding out does not necessarily imply the absence of financial crowding out. The financial crowding out may occur due to the upward pressures on the interest rate induced by the debt financing of fiscal deficit. In other words, even if public sector investment does not crowd out private corporate investment, the private capital formation in the economy may suffer due to the increase in the interest rates occurring due to the preemption of real and financial resources by the government to finance the increasing fiscal deficits. In this paper, we examine the plausibility of whether fiscal deficit affects interest rate. It is all the more important to examine such a link in the present context, as Chakraborty (2007) found that interest rate is a significant determinant of private corporate investment. If increase in fiscal deficit increases the interest rate, it would imply financial crowding out.

It is well known that the Indian financial system was characterised by administered interest rate structure until the 1990s. The process of financial deregulation since 1991 has been aimed at making the financial sector market-oriented to improve allocative efficiency. ${ }^{5}$ The debatable question is, as the interest rate was administered until the financial deregulation, how could a functional relationship be justified between fiscal deficit and the administered interest rate? Even if it is assumed that the administered interest rate truly reflects the market signals, there is a need to establish such a relationship empirically. The task of establishing such a relationship is ambiguous and might be the reason that thwarts the analysis of this link prior to the deregulation of interest rates. However, contrary to the popular belief that an administered interest rate in developing countries is insensitive to market perceptions, the literature revealed that an administered interest rate does accommodate market signals, and in order to analyze that, the literature has suggested examining the intertemporal movement of the interest rate and its

government's sale of bonds, regardless of its use of the proceeds, raises the total supply of bonds in the market. The greater supply of bonds, according to this view, means a lower bond price- that is, a higher interest rate, which reduces (crowds out) private investment.

${ }^{5}$ The major highlights of financial liberalization are interest rate deregulation, a phased reduction of cash reserve requirements and statutory liquidity ratios, simplifying directed credit programs, and development of money markets, etc. The administered interest rates were simplified beginning in 1992-93. A small number of fixed rates for priority sector loans were retained, while large commercial borrowers faced a floor-lending rate. From 1993-94, the markets for commercial paper and certificates of deposit were deregulated, allowing companies to access credit at market terms that were considerably below the minimum lending rate. In October 1994, the minimum lending rate was eliminated. The deregulation of interest rates has been accompanied by the introduction of new instruments like 14-day and 182-day auction treasury bills in addition to the 91-day and 364-day auction treasury bills. It is to be noted that the 182-day treasury bill was reintroduced in mid-1999. 
variability (Gupta 1984). The analysis of intertemporal movements in the selected interest rates adjusted for inflationary expectations also showed that the interest rates in India, though administered, have shown variations over the years, and real interest rates remained positive in a substantial number of years. Chakraborty (2007), using the annual data, established no evidence of fiscal deficit causes in interest rate determination. However, the model was not controlled for the capital flows. This paper takes the debate forward in the context of capital flows, focusing on the financially deregulated regime, using the recent high frequency data of fiscal deficit and the interest rate for the periods April 2006-07 to April 2011-12.

This paper is organized into five sections. Section 1 discusses various theoretical paradigms on the relationship between fiscal deficit and interest rates and critically evaluates the empirical literature. Section 2 discusses the theoretical model of the interest rate in an open-economy framework. Section 3 interprets data, and Section 4 deals with econometric methodology adopted and reports the results obtained. Section 5 concludes.

\section{THEORETICAL PARADIGMS AND EMPIRICAL LITERATURE}

At the theoretical level, an extensive debate has developed to explain the link between deficit and interest rate. There are three different theoretical paradigms under which this relationship can be viewed and empirically tested: neoclassical, Keynesian, and Ricardian. According to the neoclassical view, a rise in the deficit leads to an increase in the interest rate and, in turn, crowds out private investment. The Keynesians visualize that though an increase in the deficit leads to an increase in the interest rate, such an increase stimulates savings and capital formation. In between the neoclassical and Keynesian view, there exists the observation of the Ricardian Equivalence Theorem (RET), which argued that deficits merely postpone taxes and, therefore, tax financing and debt financing of deficit have equal impacts on the economy; thus, deficit does not have any impact on the interest rate (Barro 1974).

Many authors have empirically tested this relationship and found contradictory results. Evans (1985), Tanzi (1985), Dalamagas (1987), Ahmad (1994), Kulkarni and Erickson (1996) found no positive link between interest rate and deficit, while Cebula (1990), Correia and Stemitsiotis (1995), Ostrosky (1979) did find evidence for the link between deficit and interest rate. 
Table 1 Selected empirical evidences on link between fiscal deficit and interest rate

\begin{tabular}{l|l} 
Study & Results \\
\hline Evans (1985) & $\begin{array}{l}\text { Deficit does not have an impact on the interest rate in the context of the } \\
\text { US for the period 1858-1950. }\end{array}$ \\
\hline Ahmad (1994) & $\begin{array}{l}\text { No variable except inflation is significant. Monetary and fiscal policy } \\
\text { variables do not have any impact in the context of Pakistan for the } \\
\text { period 1970-91. }\end{array}$ \\
\hline Tanzi (1985) & $\begin{array}{l}\text { Sensitivity of the interest rate to fiscal deficit has decreased in the recent } \\
\text { years of the study (1980-84) in the context of the US. The entire time } \\
\text { period of the study was 1960-84. }\end{array}$ \\
\hline & Significant and positive impact of
\end{tabular}

Significant and positive impact of government deficit on the real interest

Balkan and Erol (1995) rate in the context of the UK for the period 1960-84.

Granger-caused deficit affects the interest rate in the context of the US

Cebula (1997)

for the period 1973-93.

Deficit affects the long-run interest rate in the context of 10 OECD

Correia-Nunes and Stemitsiotis (1995)

(Organisation of Economic Co-operation and Development) countries for the period of 1970-93.

RET is rejected for Sri Lanka, India, Indonesia, Philippines among 10 Asian countries for the period of 1960-85.

Gupta (1992)

Asian countries for the period of 1960-85.

\begin{tabular}{l|l} 
Kulkarni and Erickson (1996) & $\begin{array}{l}\text { Deficit does not affect the interest rate in the context of India for the } \\
\text { period of 1960-88. }\end{array}$ \\
\hline Elmendorf and Mankiw (1998) & $\begin{array}{l}\text { Fiscal deficits (ceteris paribus) reduce national savings and increase } \\
\text { aggregate demand. This creates an excess supply of government debt, } \\
\text { leading to higher real interest rates. }\end{array}$ \\
\hline Gale and Orszag (2002) & $\begin{array}{l}\text { Of } 60 \text { countries, around one-half found a "predominantly positive } \\
\text { significant" effect of fiscal deficits on interest rates, and the other half a } \\
\text { "mixed" or "predominantly insignificant" effect. }\end{array}$
\end{tabular}

The common analogy of latter set of studies is that, in a growth economy with accumulation, increasing budget deficits may create a shortage of funds available for investment over the long term. If this potential imbalance between the supply of funds and intended 
investment is not addressed, the long-term interest rate reacts as economic agents anticipate the shortage of funds. The former set of studies, which observed no link between the interest rate and fiscal deficit emphasizes that in the context of global integration of financial markets, the supply of funds curve is infinitely elastic. Also, some studies under this category tried to explain their findings under the paradigm of RET.

It is to be noted that the empirical literature on the fiscal deficit and interest rate link is largely confined to developed countries. To start with, in the context of the US, Tanzi (1985) examined the relationship between fiscal deficit and the interest rate. He observed that for the period 1960-84, the sensitivity of the interest rate to fiscal deficit decreased over the years. Tanzi pointed out that the plausible explanation of this phenomenon was the growing global integration of financial markets in recent years and correspondingly increasing flow of global capital to finance the domestic deficit. On the basis of the multivariate loanable funds model (which incorporates the effect of term structure on interest rate ), ${ }^{6}$ Cebula (1990) and CorreiaNunes and Stemitsiotis (1995) showed that deficit, inflation, short-run interest rate, percentage change in GDP, and capital flows Granger-cause the nominal long-term interest rates, and hence crowding out of private investment occurs. In Correia-Nunes and Stemitsiotis's (1995) study, which was based on cross-country data of 10 OECD countries, there was evidence of crowding out as the interest rate was positively linked to the deficit. Further, Cebula (1997) examined the direction of causality between long-term interest rates and structural budget deficits in the US for the period 1973-91, and found that there is bi-directional causality between the interest rate and the deficit. Gale and Orszag (2002) argued that interest rates do not increase as a result of fiscal expansions due to foreign capital savings replacing domestic savings. However, economic performance may still be negatively affected by persistent fiscal imbalances as capital stock accumulation declines either because of a decline in domestic or foreign net investment.

In the context of developing countries, studies are few on the link between budget deficit and the interest rate. In the context of Pakistan, Ahmad (1994) found that there is no link between interest rates and deficit. In India, paucity of data on market interest rates might be the reason for no specific studies on the causal relationship between the deficit and interest rates.

\footnotetext{
${ }^{6}$ The advantage of the loanable funds model is that in addition to capturing the monetary and fiscal variables like real deficit, real money stock, government spending, expected inflation rate, etc., it also captures the term structure of interest rates. In other words, the loanable funds model's framework allows for the combination of the characteristics of the term-structure with the fiscal and monetary policy variables, influencing the interest rate.
} 
Sundararajan and Thakur (1980), Pradhan, Ratha, and Sarma (1980), and Parker (1995)

addressed the issue of "direct" crowding out between public and private investment in India, but these studies did not analyze the macroeconomic link of fiscal deficit and interest rates through which the crowding out phenomena should theoretically be operating.

\section{ANALYTICAL FRAMEWORK}

The analytical framework for the study is derived from an extended version of Sargent's (1969) paper "Commodity Price Expectations and the Interest Rate." The extended version of Sargent's model is flexible enough to incorporate the macroeconomic link that may operate in the determination of interest rates. Sargent (1969) expressed the nominal interest rate as a combination of three components: the equilibrating interest rate, the spread between market interest rate and the equilibrating real interest rate, and the spread between nominal interest rate and market interest rate. It can be expressed as follows.

$$
r_{n(t)}=r_{e(t)}+\left[r_{m(t)}-r_{e(t)}\right]+\left[r_{n(t)}-r_{m(t)}\right]
$$

In equation $(1), r_{n(t)}$ is the nominal interest rate, $r_{e(t)}$ is the real interest rate that equilibrates desired savings and desired investment, and $r_{\mathrm{m}(\mathrm{t})}$ is the nominal interest rate adjusted for the expected rate of inflation. Each of the three specific components is determined in turn by specific macroeconomic variables. The logical step that follows is to identify the determinants of each of the three terms in equation (1). ${ }^{7}$ One of the significant determinants of the first term, $r_{e(t)}$, which is the real interest rate that equilibrates desired savings and desired investment, is the deficit of the government. $^{8}$

$$
r_{e(t)}=\alpha+\beta_{1}\left(\operatorname{def}_{t}\right)+\mu_{t}
$$

\footnotetext{
${ }^{7}$ The derivations of determinants of each term in the model are drawn from Gupta and Moazzami (1996). But as the objective of their study was to test the validity of alternative paradigms of the link between deficit and interest rate - neoclassical, Keynesian, and Ricardian Equivalence Theorem - across countries and to distinguish between the short-term and long-term impact of deficits on interest rate, we have not drawn heavily on the derivations of the determinants of the model; rather we improvise the specification according to our purpose to undertake the impact of fiscal deficit on the interest rate in the context of India, irrespective of the paradigm-specific details and the dichotomy of transitory and permanent effects of deficits on the interest rate .

${ }^{8}$ The other determinants of term (1) in the Gupta-Moazzami model constituted government consumption expenditure, national income, private consumption expenditure, private savings, etc., which we omit in our specification due to multicollinearity problems, and moreover, these explanatory variables are not required for our analysis as we have not gone into the testing of validity of each of the alternative paradigms of fiscal deficit and interest rate in the context of India; rather, our prime concern was to assess the role of fiscal deficit in the interest rate to understand the transmission channel of the crowding out phenomenon.
} 
The determinant of the second term, $\left[r_{m(t)}-r_{e(t)}\right]$, is determined by the growth rate of highpowered money. ${ }^{9}$ In the open economy model, capital flows also determine the spread between the market rate and the equilibrium real interest rate. The real exchange rate can also be inserted into the equation (3) to capture the effect on the interest rate in an open economy macro model. Assuming linearity, we thus have:

$$
r_{m(t)}-r_{e(t)}=\lambda+\beta_{2}\left(\Delta M_{3}\right)_{t}+\beta_{3}\left(K_{r}\right)_{t}+\delta_{t}
$$

where $\left(\Delta M_{3}\right)_{t}=$ changes in high powered money and $\left(K_{r}\right)_{t}=$ net capital flows.

The last term of equation (1) is assumed to depend linearly and positively on the inflationary expectations.

$$
r_{n(t)}-r_{m(t)}=\theta+\beta_{4}\left(\pi_{t}^{e}\right)+v_{t}
$$

where, $\pi_{t}^{e}=$ Expected Rate of Inflation

Now by substituting equation (2), (3) and (4) in equation (1), we get equation (5):

$$
r_{n(t)}=\varphi+\beta_{1}\left(\operatorname{def}_{t}\right)+\beta_{2}\left(\Delta M_{3}\right)_{t}+\beta_{3}\left(e_{r}\right)_{t}+\beta_{4}\left(\pi_{t}^{e}\right)+\omega_{t}
$$

According to equation (5), interest rate is a function of fiscal deficits, change in highpowered money, capital flows and expected inflation. Capital flows are an important variable for the model, especially when the period under study experiences volatility in capital flows; therefore, controlling for this fluctuation in liquidity, whether fiscal deficit affects interest rate or not is an interesting aspect to examine. The above theoretical derivation is econometrically estimated.

Each of these determinants is linked to the interest rate through various macroeconomic channels; a few are attempted as follows. The unsettled relationship between money supply and interest rate is reviewed extensively by Nachane, Karnik, and Hatekar (1997). These are mainly unanticipated monetary announcement effect, Keynesian liquidity effect, financial effect, price expectations effect (Fisher effect), and income effect. Due to unanticipated monetary announcement effect, permanent higher money growth rate induces an increase in expected inflation and a resulting increase in interest rates to reflect an inflation premium (Girton and Nattress 1985). According to the Keynesian "liquidity effect," income and prices are slow to react as the money supply increases, and thus the monetary system experiences excess liquidity at unchanging nominal income levels. Contemporaneous with the liquidity effect, there runs the

\footnotetext{
${ }^{9}$ For details, see Sargent (1969).
} 
financial effect. As per the financial effect, as the growth of money increases, banks find themselves saddled with excess reserves, and these excess reserves have to be temporarily parked in short-term market securities. This temporary spurt in the demand for short-term marketable securities lowers short-term interest rates. When the money supply increases with the rise in income, the demand for money rises. As a result, the real balance of the economy decreases, finally pushing up the nominal interest rate.

Price expectation effect (Fisher Effect) shows that when money supply increases, the expected inflation increases and thereby the nominal interest rate also increases. All five effects will be present in any given situation, though their duration, strength, and timing are largely an empirical matter and will vary from situation to situation. The relationship between monetary expansion and interest rate has been obscure in the empirical literature. While Mishkin (1982) found that the interest rate and money growth surprises have a significant positive correlation, Makin (1983) found that it is negative and significant. Makin explained these contradictory findings were as a result of the different method used to measure interest rates. Makin implied that his period-average short-term interest rate is responding to the initial liquidity effect, while Mishkin's end-of-period short-term interest rate measure is sampled after the Fisher effect begins to dominate. Grier (1986) also showed that lagged money surprises have a significant positive impact on rates.

Fisherian theory predicts that the nominal interest rate will tend to change at the same rate as changes in expected inflation. Thus, it manifests a one-to-one relationship between the expected inflation and the nominal interest rate. According to Fisher's equation, a one-percent increase in the expected rate of inflation, in turn, causes a one-percent increase in the nominal interest rate. Only a few studies in the context of the US by Feldstein (1976) and Gibson (1970) found coefficients close to unity. But Sargent (1976), Shiller (1979), and Wood (1981) observed that these findings of "coefficients close to unity" are limited to a particular period of US history, until the early 1970s. Furthermore, even a unit coefficient would contradict the superneutrality hypothesis- that an increase in inflation will not affect real interest rates in the long run.

Robert Lucas (1980) finds no empirical support for the hypothesis, which he calls one of the central implications of the quantity theory of money. Beginning with Irving Fisher (1930), most of the empirical investigations have discovered that fully anticipated inflation has less than a unit effect on the nominal interest rate, and thus reduces the real interest rate even in the longest of runs. Fama (1975) concluded that "one ... cannot reject the hypothesis that all variation through time in 
one-to-six month nominal rates of interest mirrors variation in correctly assessed one-to-six month expected rates of purchasing power." Fama's conclusion rests on two assumptions: (1) there is a constant expected real interest rate and (2) all relevant information about future inflation is fully incorporated in the expected-inflation component of the market interest rate. Both assumptions are contradicted by evidence by Carlson (1977). Carlson pointed out that variations in short-term interest rates are not good predictors of variations in inflation rates. Furthermore, both of the key assumptions are of dubious validity. Evidence has been presented that expected short-term real interest rates do have notable variation.

Under the scenario of large capital flows in a flexible exchange rate regime, the nominal exchange rate appreciation leads to the deterioration of international competitiveness. So to prevent the real appreciation of the exchange rate and to preserve external competitiveness, the central bank intervenes in the Forex market to sterilize the incremental liquidity thus generated, thereby keeping the monetary expansion under control. This process has, however, quasi-fiscal costs associated with it, as it imposes the danger of increasing the real interest rate, which can further induce the capital flows. Another explanation is that an increase in the exchange rate of the previous year would make the domestic currency less valued in the international market, and therefore would attract the demand for domestic financial assets from abroad. This may lead to increase in the interest rate. Capital flows have been incorporated in the macro model; however, exchange rate is dropped in the econometric model for empirical reasons of non-stationary series as well as multicollinearity between capital flows and exchange rate.

\section{INTERPRETING DATA}

Data is organized from the high frequency series of macro variables from the data bank of RBI. Selection of the appropriate interest rate from the available spectrum of interest rates in India for an elaborate analysis of the link between interest rate and fiscal deficit is the crucial step in data mining. The major interest rates are call money market rate, bank rate, treasury bill rates (91 days, 364 days, and 182 days), bank rate, prime lending rate of term lending institutions, and interest rate on dated securities of the government of India. Among these interest rates, call money market rate has exhibited large volatility and the bank rate has appeared to be nonvarying in nature, which intuitively can be opted out in analyzing the link between fiscal deficit and interest rate. Long-term interest rates are also opted out as a reference rate. Prime lending 
rate is relevant as it is a significant determinant of private investment behavior, but opted out as it is a long-term rate and has also shown a broad stickiness in the rates. The redemption yield on dated securities of India is identified on the grounds that a shift from seigniorage financing to bond financing of fiscal deficit in India can have some pressure on the interest rate-especially the interest rate on bonds or securities-but opted out as it is long-term. Treasury bill rate is identified as the reference interest rate. Theoretically, a reference rate is defined as the price of a short-term low risk instrument in a free liquid market. The weighted averages of treasury bill rates of 91 days, 182 days, and 364 days are used as the interest rate variable in this paper. However, the determination of long-term interest rates, in particular, the government securities rate, and the role of fiscal deficit in determining the longs is also analyzed outside the purview of reference rate analysis at the later stage, as the interest rate on government security is also an important rate especially when government securities constitute a major chunk of bond financing of deficit in India.

Having selected the relevant interest rates for the analysis, the next task is to transform these interest rates into ex ante real interest rate. According to the Fisher hypothesis, nominal interest rate $(\gamma \mathrm{n})$ is given by

$$
\gamma^{\mathrm{n}}=\gamma^{\mathrm{r}}+\pi^{\mathrm{e}}
$$

where $\gamma^{\mathrm{r}}$ is the real interest rate and $\pi^{\mathrm{e}}$ is the expected rate of inflation. The real interest rate in any period, thus, is postulated to evolve as a deviation between nominal interest rate and the expected inflation. Correia-Nunes and Stemitsiotis (1995) used the low frequency component of consumer price changes as generated by the Hodrick-Prescott (HP) filter to model expected inflation. We use the HP filter for computing expected inflation. ${ }^{10}$

Using the HP filter, how do we capture expected inflation from the observed series ${ }^{11}$

Let us assume that observed inflation $\pi$ contains both expected $\pi^{\mathrm{e}}$ and unexpected components $\pi^{\mathrm{u}}$

\footnotetext{
${ }^{10}$ Apart from the HP filter method, various other econometric methods have also been employed to construct appropriate proxies for the market's expectations of future inflation. Tanzi (1985) used surveys of inflationary expectations such as Livingston index to generate a series on expected inflation in the context of the US. Autoregressive models have also been used to generate a series of expected inflation.

${ }^{11}$ The HP filter has good mathematical properties in order to extract the unobservable variable of expected inflation out of the observed series. The expected inflation series computed using the HP filter contains both forward- and backward-looking information on inflation rates, which makes it relevant in a rational expectations framework. Past information is necessary to adjust prices from a disequilibrium position, while information regarding future trends is also required because rational economic agents look forward in time to form expectations about the future inflation rate (Correia-Nunes and Stemitsiotis 1995).
} 


$$
\pi=\pi^{\mathrm{e}}+\pi^{\mathrm{u}}
$$

The HP filter decomposes observed inflation into a stationary cyclical component and a smooth trend component ( $\pi$ and $\pi^{\mathrm{e}}$ denote the logarithms of observed and expected inflation, respectively) by minimizing the variance of the cyclical component subject to a penalty for the variation in the second difference of the trend component. This results in the following constrained least square problem.

$$
\begin{aligned}
& \text { i } \mathrm{T} \\
& \operatorname{Min} \sum\left(\pi-\pi^{\mathrm{e}}\right)^{2}+\lambda \sum\left[\left(\pi^{\mathrm{e}}{ }_{\mathrm{t}+1^{-}}-\pi^{\mathrm{e}}{ }_{\mathrm{t}}\right)-\left(\pi^{\mathrm{e}}{ }_{\mathrm{t}^{-}} \pi^{\mathrm{e}}{ }_{\mathrm{t}-1}\right)\right]^{2} \\
& \mathrm{~T}=1 \quad \mathrm{t}=2
\end{aligned}
$$

The same procedure through the HP filter methodology is also used to derive the unanticipated component in the reserve money, as well as the money supply, by decomposing the series into cyclical and structural components.

\section{ECONOMETRIC ESTIMATION OF THE INTEREST RATE MODEL AND RESULTS}

A significant debate exists in the time series literature on performing the pretests of integration and co-integration (Todo and Yamamoto 1995). A stationary times series are integrated of order zero, $x t \sim \mathrm{I}(0)$. The time series econometrics encounters problems: how to involve a mixture of $\mathrm{I}(0)$ and non-stationary $\mathrm{I}(\mathrm{d})$ series, where the order of integration $d$ can be different for different series and even fractional, and where the stationarity assumptions are difficult to verify. A few attempts to eliminate these problems of pretests for vector autoregressions (VAR) can be found in econometric literature, the prominent being the methodology by Todo and Yamamoto (1995) and Vinod (2006).

Getting to theoretical basics of economics, Samuelson (1947) explained economic equilibrium as describing a given set of "functional equations and initial conditions describing relationships between variables ... for the purpose of determining the evolution of a set of economic variables through time," and therefore converting economic time series to stationarity via differencing transformation justified by unit root testing is problematic for evolutionary short series (Vinod 2006). The entire debate on unit roots has roots in the work of Nelson and Plosser (1982), which suggested that most of the macroeconomic variables have a unit root time-series structure. For instance, there is a considerable amount of debate about the stationary properties of prices. While Perron (1989), Levin and Lin (1992), Culver and Papell (1997) 
suggested that inflation is a stationary series, other studies in the multivariate country contexts by Baillie, Chung, and Tieslau (1996), Baillie (1989), Ball and Cecchetti (1990), and Johansen (1992) found evidence in favor of unit roots in price series. This debate poses a serious need revisit to the macroeconometrics, which assumes inflation as a unit root macroeconomic variable. This debate on the unit root properties can be extended to other macro variables: namely, deficits, interest rate, exchange rate, capital flows, and money supply, as well.

Against the backdrop of this debate, the methodology used in this paper is not an attempt to avoid the difficult inference problems associated with unit root testing, but rather proposes a judicious selection of macro variables to avoid the mixing of $\mathrm{I}(0)$ and $\mathrm{I}(\mathrm{d})$ variables, and care is taken to protect the time series properties of the macro variables by not succumbing to a detrending or differencing process during the pretests. The unit roots are initially performed through the augmented Dickey-Fuller (ADF) methodology. However, as suggested by Perron (1989), ADF has a tendency not to reject the null hypothesis of unit root when the series has a structural break. A test for structural breaks has been attempted by deciding apriori the units of break, and the growth rate analysis of both subsets of time periods were analyzed and no significant difference between the coefficients was found. ${ }^{12}$ Table 2 reports the unit roots performed on the macro series used in the study.

Table 2 Augmented Dickey-Fuller (ADF) inference on unit roots

\begin{tabular}{c|c|c|c|c} 
Macro Variables & T-stat & $\begin{array}{c}\text { McKinnon } \\
\text { Critical Values }\end{array}$ & Lags & \multicolumn{1}{|c}{ Decision } \\
\hline rgfd & -3.72621 & $\begin{array}{c}-2.6013 \\
\text { (at } 1 \%)\end{array}$ & 0 & $\mathrm{I}(0)$ with no c,t \\
\hline TB-rroi & -2.22177 & $\begin{array}{l}-1.9462 \\
\text { (at 5\%) }\end{array}$ & 2 & $\mathrm{I}(0)$ with no c,t \\
\hline TB-eroi & -1.65794 & $\begin{array}{l}-1.6187 \\
(\text { at } 10 \%)\end{array}$ & 2 & $\mathrm{I}(0)$ with no c,t \\
\hline ewpi & -3.48682 & $\begin{array}{l}-2.6013 \\
(\text { at } 1 \%)\end{array}$ & 0 & $\mathrm{I}(0)$ with no c,t \\
\hline Kflows & -3.95941 & $\begin{array}{l}-2.6019 \\
(\text { at } 1 \%)\end{array}$ & 0 & $\mathrm{I}(0)$ with no c,t \\
\hline Pfolio & -8.42229 & $\begin{array}{l}-2.6013 \\
(\text { at } 1 \%)\end{array}$ & 0 & $\mathrm{I}(0)$ with no c,t \\
\hline
\end{tabular}

\footnotetext{
12 The potential existence and timing of structural breaks in the series could also be attempted through Zivot and Andrews' (1992) test, which identifies possible periods of structural break in the time series based upon a series of dummy variable constructs. If the dummy variables are statistically significant, the precise time of the structural break can be determined based on a max $R^{2}$ criteria.
} 


\begin{tabular}{c|c|c|c|l}
\hline uhpm & -2.82898 & $\begin{array}{l}-2.6013 \\
(\text { at } 1 \%)\end{array}$ & 0 & I(0) with no c,t \\
\hline B-roi & -3.806301 & $\begin{array}{l}-3.5457 \\
(\text { at } 1 \%)\end{array}$ & 2 & I(0) with c, no t \\
\hline Lrroi & -3.195627 & $\begin{array}{l}-2.6033 \\
(\text { at } 1 \%)\end{array}$ & 3 & I(0) with no c,t \\
\hline Elroi & -4.720559 & $\begin{array}{l}-4.1219 \\
(\text { at } 1 \%)\end{array}$ & 2 & I(0) with c,t
\end{tabular}

Source: Reserve Bank of India (2002), basic data

Table 3 Phillips-Perron (PP) inference on unit roots

\begin{tabular}{|c|c|c|c|c|}
\hline Macro Variables & $\begin{array}{c}\text { PP } \\
\text { T-stat }\end{array}$ & Lags & Critical Values & Decision \\
\hline rgfd & -3.72621 & 0 & $\begin{array}{r}-2.6013 \\
(\text { at } 1 \%) \\
\end{array}$ & $\mathrm{I}(0)$ with no $\mathrm{c}, \mathrm{t}$ \\
\hline TB-rroi & -1.816985 & 2 & $\begin{array}{l}-1.6186 \\
(\text { at } 10 \%) \\
\end{array}$ & $\mathrm{I}(0)$ with no $\mathrm{c}, \mathrm{t}$ \\
\hline \multirow[t]{2}{*}{ TB-eroi } & -1.81699 & 2 & $\begin{array}{l}-1.6186 \\
\text { (at } 10 \%)\end{array}$ & $\mathrm{I}(0)$ with no $\mathrm{c}, \mathrm{t}$ \\
\hline & -2.06752 & 4 & $\begin{array}{l}-1.9459 \\
(\text { at } 5 \%) \\
\end{array}$ & $\mathrm{I}(0)$ with no $\mathrm{c}, \mathrm{t}$ \\
\hline ewpi & -3.48682 & 0 & $\begin{array}{l}-2.6013 \\
(\text { at } 1 \%) \\
\end{array}$ & $\mathrm{I}(0)$ with no $\mathrm{c}, \mathrm{t}$ \\
\hline uma & -3.95941 & 0 & $\begin{array}{l}-2.6019 \\
(\text { at } 1 \%) \\
\end{array}$ & $\mathrm{I}(0)$ with no $\mathrm{c}, \mathrm{t}$ \\
\hline Kflows & -6.42229 & 0 & $\begin{array}{l}-2.6013 \\
(\text { at } 1 \%) \\
\end{array}$ & $\mathrm{I}(0)$ with no $\mathrm{c}, \mathrm{t}$ \\
\hline pfolio & -8.11423 & 0 & $\begin{array}{l}-2.6013 \\
(\text { at } 1 \%) \\
\end{array}$ & $\mathrm{I}(0)$ with no $\mathrm{c}, \mathrm{t}$ \\
\hline uhpm & -2.82898 & 0 & $\begin{array}{l}-2.6013 \\
(\text { at } 1 \%) \\
\end{array}$ & $\mathrm{I}(0)$ with no $\mathrm{c}, \mathrm{t}$ \\
\hline B-roi & -2.862993 & 3 & $\begin{array}{l}-2.5923 \\
(\text { at } 10 \%) \\
\end{array}$ & $\mathrm{I}(0)$ with $\mathrm{c}$, no $\mathrm{t}$ \\
\hline Lrroi & -2.106247 & 5 & $\begin{array}{l}-1.9459 \\
(\text { at } 5 \%) \\
\end{array}$ & $\mathrm{I}(0)$ with no $\mathrm{c}, \mathrm{t}$ \\
\hline Elroi & -3.282140 & 3 & $\begin{array}{c}-4.1162 \\
(1 \%)\end{array}$ & $\mathrm{I}(0)$ with $\mathrm{c}, \mathrm{t}$ \\
\hline
\end{tabular}

Source: Reserve Bank of India (2002), basic data

The ADF and PP tests of unit roots revealed that the macro variables for the study are stationary at levels with no drift and trend. Therefore, the logical next step that follows is to analyze the causality. Toda and Yamamoto (1995) developed an alternative causality testing procedure based on the test equations of Granger, but augmented with extra lags depending on the potential order of integration of the series of interest. If the series are assumed I(1), one extra lag is added to each variable in the test equation. If both variables are assumed $\mathrm{I}(0)$, no extra lag 
is added in the equation, and the Toda-Yamamoto test is equivalent to the Granger Causality test. A Wald Test is carried out to determine the relationship between the two variables. However, Hsiao (1981) is used in this paper as it simultaneously identifies the optimal parameterization of the model and the causality directions. The optimal parameterization is attempted in Hsiao (1981) through Final Prediction Error (FPE).

Vector Auto Regression models can be written in general form as

$\mathrm{y}_{\mathrm{t}}=\alpha+\psi(\mathrm{L}) \mathrm{y}_{\mathrm{t}}+\mu_{\mathrm{t}}$

where $y_{t}$ is vector of model variables

$\alpha$ is vector of constants

$\mu_{t}$ is vector of white noise error terms

$\psi(\mathrm{L})$ is vector of polynomials in the lag operator, $\mathrm{L}$

where $\varphi_{i j}=\sum_{t=1}^{k} \varphi_{i j i} L^{i}$ where $\mathrm{L}$ is the lag operator

$\mu_{\mathrm{t}}$ and $\nu_{\mathrm{t}}$ are white noise error terms.

To choose the order of lags in $\psi_{\mathrm{ii}}(\mathrm{L})$ and $\psi_{\mathrm{ij}}(\mathrm{L})$ by the minimum FPE is equivalent to applying an approximate $\mathrm{F}$ test with varying significance levels; for details, see Hsiao (1981).

Akaikes' definition of Final Prediction Error criteria is expressed as

$$
F P E_{y}(m, n)=\frac{T+m+n+1}{T-m-n-1} * \frac{\sigma^{2} y(m, n)}{T}
$$

where $\mathrm{T}$ is the number of observations, $\mathrm{m}$ and $\mathrm{n}$ are the order of lags of the variables concerned-private corporate investment $[\mathrm{y}]$ and determinants $\left[\mathrm{x}_{\mathrm{s}}\right]$, respectively, and

$$
\sigma^{2} y(m, n)=\sum_{t=1}^{T}\left(y_{t}-\psi^{m}{ }_{i i}(L) y_{t}-\hat{\psi}^{n}{ }_{i j}(L) x_{s_{t}}-\hat{a}\right)^{2}
$$

where superscripts $m$ and $n$ denote the order of lags in $\psi_{11}(\mathrm{~L})$ and $\psi_{12}(\mathrm{~L})$. And $\psi^{\mathrm{m}}{ }_{11}(\mathrm{~L}), \psi^{\mathrm{n}}{ }_{12}$ (L) $\mathrm{x}_{\mathrm{st}}$ and $\hat{a}$ are the least square estimates. The causality can be detected as follows: If FPE $\mathrm{y}$ $(\mathrm{m}, \mathrm{n})<$ FPE $\mathrm{y}(\mathrm{m}, 0)$ then $\mathrm{x}_{(\mathrm{s}) \mathrm{t}}$ Granger causes $\mathrm{y}_{\mathrm{t}}$, denoted by $\mathrm{x}_{(\mathrm{s}) \mathrm{t}} \Rightarrow \mathrm{y}_{\mathrm{t}}$.

In the multivariate autoregressive modeling, the sequence in which variables enter the equation matters. We used Specific Gravity Criteria suggested by Caines, Keng, and Sethi (1981) for sequencing the variables. Caines, Keng, and Sethi (1981) suggested the following procedure for multivariate autoregressive modeling for stationary processes: 
(1) For a pair of stationary processes $(X, Y)$, construct bivariate AR models of different orders, then compare the multivariate final prediction errors of these models and choose the model of order $\mathrm{k}$ possessing minimum FPE to be the optimal model for the pair of processes $(\mathrm{X}, \mathrm{Y})$.

(2) Construct bivariate AR (k) models (both causal models and non-causalindependent—-models) for (X, Y) and apply the stage wise causality detection procedure to determine the endogeneity, exogeneity, or independent relations between $\mathrm{X}$ and $\mathrm{Y}$.

(3) If a process, say $X$, has $n$ multiple causal variables, $y^{1}, y^{2}, \ldots, y^{n}$, we rank these multiple causal variables according to the decreasing order of their specific gravities.

(4) For each caused (endogenous) process, X, we first construct the optimal univariate AR model using FPE criterion, then we include X's multiple causal variables, one at a time, according to their causal ranks and use FPE criterion to determine the optimal orders of the model at each step.

(5) Pool all the optimal univariate AR models constructed in (4) and estimate the system. The final prediction error (FPE) of fitting one dimensional autoregressive process for fiscal deficit (DEF) and interest rate (TB) are computed with upper bound of lag length $\left(\mathrm{L}^{*}\right)$ assumed equal to 15 . First, we have considered real interest rate as a controlled variable, and holding the order of its autoregressive operator to one, we sequentially added the lags of the manipulated variables up to the $\mathrm{L}^{*}$ of 15 . In this treatment of real interest rate as the manipulated variable, we found that $\operatorname{FPE}_{\mathrm{DEF}}\left(\mathrm{m}^{*}, \mathrm{n}^{*}\right)>\operatorname{FPE}_{\mathrm{DEF}}\left(\mathrm{m}^{*}, 0\right)$, which implies fiscal deficit does not Granger-cause the interest rate. However, the changes in money supply, exchange rate, and inflationary expectations determines the interest rate.

Table 4 Shorts - Optimal parameterization and causality detection

\begin{tabular}{|c|c|c|c|c|c|c|c|}
\hline \multirow{2}{*}{$\begin{array}{c}\begin{array}{c}\text { Controlled } \\
\text { Variable }\end{array} \\
\left(i_{r}-\pi_{t}^{e}\right)[1]\end{array}$} & \multicolumn{4}{|c|}{ Manipulated Variables } & \multirow{2}{*}{$\begin{array}{c}\begin{array}{c}\text { Optimum } \\
\text { Lags of } \\
\text { Manipulated } \\
\text { Variable }\end{array} \\
1\end{array}$} & \multirow{2}{*}{$\begin{array}{c}\begin{array}{c}\text { Final } \\
\text { Prediction } \\
\text { Error }\end{array} \\
0.37445\end{array}$} & \multirow[t]{2}{*}{$\begin{array}{l}\text { Causality } \\
\text { Inference }\end{array}$} \\
\hline & - & - & - & - & & & \\
\hline$\left(i_{r^{-}}-\pi_{t}^{e}\right)[1]$ & $(\operatorname{expinf})_{\mathrm{t}}$ & - & - & - & 4 & 0.29759 & $(\operatorname{expinf}) \mathrm{t} \Rightarrow\left(\mathrm{i}_{\mathrm{r}^{-}} \pi_{\mathrm{t}}^{\mathrm{e}}\right)$ \\
\hline$\left(i_{r^{-}} \pi_{t}^{e}\right)[1]$ & $(\operatorname{expinf})_{\mathrm{t}}$ & $\Delta \mathrm{hpm}_{\mathrm{t}}$ & - & - & 3 & 0.29998 & $\Delta \mathrm{hpm} \Rightarrow\left(\mathrm{i}_{\mathrm{r}^{-}} \pi_{\mathrm{t}}^{\mathrm{e}}\right)$ \\
\hline$\left(i_{r}-\pi_{t}^{e}\right)[1]$ & $(\operatorname{expinf})_{\mathrm{t}}$ & $\Delta \mathrm{hpm}_{\mathrm{t}}$ & $(\text { Kflows })_{\mathrm{t}}$ & - & 1 & 0.31025 & $(e r)_{t} \Rightarrow\left(i_{r^{-}}-\pi_{t}^{e}\right)$ \\
\hline
\end{tabular}




\begin{tabular}{|c|c|c|c|c|c|c|c|}
\hline$\left(\mathrm{i}_{\mathrm{r}}-\pi_{\mathrm{t}}^{\mathrm{e}}\right)[1]$ & $(\text { expinf })_{t}$ & $\Delta \mathrm{hpm}_{\mathrm{t}}$ & $(\text { Kflows })_{\mathrm{t}}$ & $\operatorname{def}_{t}$ & 1 & 0.38971 & $\operatorname{def}_{t} \neq\left(i_{r^{-}} \pi_{t}^{e}\right)$ \\
\hline$(\mathrm{def}) \mathrm{t}[1]$ & - & - & - & - & 1 & 0.79837 & \\
\hline$(\mathrm{def}) \mathrm{t}[1]$ & $\left(i_{r^{-}}-\pi_{t}^{e}\right)$ & - & - & - & 5 & 0.61938 & $\left(\mathrm{i}_{\mathrm{r}}-\pi_{\mathrm{t}}^{\mathrm{e}}\right) \Rightarrow(\mathrm{def})_{\mathrm{t}}$ \\
\hline$(\mathrm{def}) \mathrm{t}[1]$ & $\left(\mathrm{i}_{\mathrm{r}^{-}}-\pi_{\mathrm{t}}^{\mathrm{e}}\right)$ & $(\text { expinf })_{t}$ & - & - & 4 & 0.55429 & $(\operatorname{expinf})_{t} \Rightarrow(\operatorname{def})_{t}$ \\
\hline$(\operatorname{def}) t[1]$ & $\left(i_{r}-\pi_{t}^{e}\right)$ & $(\operatorname{expinf})_{\mathrm{t}}$ & $\Delta \mathrm{hpm}_{\mathrm{t}}$ & - & 1 & 0.03059 & $\Delta \mathrm{hpm}_{\mathrm{t}} \Rightarrow(\mathrm{def})_{\mathrm{t}}$ \\
\hline$(\mathrm{def}) \mathrm{t}[1]$ & $\left(i_{r}-\pi_{t}^{e}\right)$ & expinf) ${ }_{t}$ & $\Delta \mathrm{hpm}_{\mathrm{t}}$ & $(\text { Kflows })_{\mathrm{t}}$ & 1 & 0.59671 & Kflows $)_{t} \Rightarrow(\text { def })_{t}$ \\
\hline
\end{tabular}

Note: Figures in the parentheses denotes the lag length of controlled variable.

Source: Reserve Bank of India, basic data

Table 5 Longs - Optimal parameterization and causality detection

\begin{tabular}{|c|c|c|c|c|c|c|c|}
\hline \multirow{2}{*}{$\begin{array}{c}\begin{array}{c}\text { Controlled } \\
\text { Variable }\end{array} \\
1\left(\mathrm{i}_{\mathrm{r}}-\pi_{\mathrm{t}}^{\mathrm{e}}\right)[1]\end{array}$} & \multicolumn{4}{|c|}{ Manipulated Variables } & \multirow{2}{*}{$\begin{array}{c}\begin{array}{c}\text { Optimum } \\
\text { Lags of } \\
\text { Manipulated } \\
\text { Variable }\end{array} \\
3\end{array}$} & \multirow{2}{*}{$\begin{array}{c}\begin{array}{c}\text { Final } \\
\text { Prediction } \\
\text { Error }\end{array} \\
0.10907\end{array}$} & \multirow[t]{2}{*}{$\begin{array}{l}\text { Causality } \\
\text { Inference }\end{array}$} \\
\hline & - & - & - & - & & & \\
\hline $1\left(i_{r}-\pi_{t}^{e}\right)[1]$ & $(\text { expinf })_{t}$ & - & - & - & 4 & 0.099105 & $($ expinf $) t \Rightarrow 1\left(i_{r}-\pi_{t}^{e}\right)$ \\
\hline $1\left(\mathrm{i}_{\mathrm{r}}-\pi_{\mathrm{t}}^{\mathrm{e}}\right)[1]$ & $(\text { expinf })_{t}$ & $(\text { Kflows })_{\mathrm{t}}$ & - & - & 2 & 0.102801 & Kflows $\Rightarrow 1\left(i_{r^{-}}-\pi_{t}^{e}\right)$ \\
\hline $1\left(i_{r^{-}}-\pi_{t}^{e}\right)[1]$ & $(\text { expinf })_{t}$ & $(\text { Kflows })_{\mathrm{t}}$ & $\Delta \mathrm{hpm}_{\mathrm{t}}$ & - & 1 & 0.11289 & $\Delta \mathrm{hpm}_{\mathrm{t}} \neq 1\left(\mathrm{i}_{\mathrm{r}}-\pi_{\mathrm{t}}^{\mathrm{e}}\right)$ \\
\hline $1\left(i_{r}-\pi_{t}^{e}\right)[1]$ & $(\text { expinf })_{t}$ & $(\text { Kflows })_{\mathrm{t}}$ & $\Delta \mathrm{hpm}_{\mathrm{t}}$ & $\operatorname{def}_{t}$ & 2 & 0.111701 & $\operatorname{def}_{\mathrm{t}} \neq\left(\mathrm{i}_{\mathrm{r}^{-}}-\pi_{\mathrm{t}}^{\mathrm{e}}\right)$ \\
\hline$(\operatorname{def}) t[1]$ & - & - & - & - & 1 & 0.79837 & \\
\hline$(\mathrm{def}) \mathrm{t}[1]$ & $1\left(i_{r}-\pi_{t}^{e}\right)$ & - & - & - & 2 & 0.79701 & $\left(\mathrm{i}_{\mathrm{r}}-\pi_{\mathrm{t}}^{\mathrm{e}}\right) \Rightarrow(\mathrm{def})_{\mathrm{t}}$ \\
\hline$(\mathrm{def}) \mathrm{t}[1]$ & $1\left(i_{r_{1}}-\pi_{t}^{e}\right)$ & $\Delta \mathrm{hpm}_{\mathrm{t}}$ & - & - & 1 & 0.86965 & $\Delta \mathrm{hpm}_{\mathrm{t}} \neq(\mathrm{def})_{\mathrm{t}}$ \\
\hline$(\mathrm{def}) \mathrm{t}[1]$ & $1\left(\mathrm{i}_{\mathrm{r}}-\pi_{\mathrm{t}}^{\mathrm{e}}\right)$ & $\Delta \mathrm{hpm}_{\mathrm{t}}$ & $(\text { expinf })_{t}$ & - & 1 & 0.701897 & $(\text { expinf })_{t} \Rightarrow(\text { def })_{t}$ \\
\hline$(\mathrm{def}) \mathrm{t}[1]$ & $1\left(i_{r}-\pi_{t}^{e}\right)$ & $\Delta \mathrm{hpm}_{\mathrm{t}}$ & $(\text { expinf })_{t}$ & $(\text { Kflows })_{t}$ & 1 & 0.731074 & Kflows $)_{t} \Rightarrow(\text { def })_{t}$ \\
\hline
\end{tabular}

Note: Figures in the parentheses denotes the lag length of controlled variable.

Source: Reserve Bank of India, basic data

To examine whether there exists reverse causality between fiscal deficit and real interest rate, we repeated the experiment, keeping fiscal deficit as the controlled variable and sequentially added the lags of manipulated variables to the set. Tables 4 and 5 present the results of Hsiao autoregressive modeling of causality detection for the shorts and longs. The results 
showed that in the context of recent financial liberalisation and deregulation of interest rates, deficit does not induce a rise in interest rate. Rather, the direction of causality runs from real interest rate to deficit. This result is in conformity of the recent trend in Indian public finance where the share of non-interest expenditure in total expenditure is on the decline. This is due to the sharp increase in interest payment obligations stemming from the rising cost of servicing the internal debt. The reason behind this can be attributed to interest rate deregulation, where the high interest rate fueled the accumulation of more debt through increase in interest payments and the consequent debt-deficit spiral. It is also found that in the deregulated financial regime, the interest rate is primarily determined by the inflationary expectations in the economy. The result is true for the interest rate determination of shorts and longs.

\section{CONCLUSION}

This paper examined whether there is any evidence of financial crowding out in the recent years of financially deregulated interest rate regime. Using the high frequency macrodata, we found quite contrary to the popular belief that increase in fiscal deficit induces a rise in the interest rate, that there exists no significant relationship between the two. The conclusion drawn from the multivariate vector autoregressive analysis for the period from FY 2006[4] to FY 2011[4] revealed that the interest rate is affected by the unanticipated components of high-powered money, expected inflation, and fluctuations in capital flows. As the causality is not established from fiscal deficits to interest rates, the plausible evidence for nil financial crowding out is reinforced in the Indian context.

A reverse causality runs from real interest rate to deficit. This result is in conformity with the recent trend in Indian public finance where the share of non-interest expenditure in total expenditure is on the decline because of the sharp rise in interest payment. One of the principal reasons for the sharp increase in interest payment obligation is the rising cost of servicing the internal debt. The reason behind this can be attributed to interest rate deregulation, where the high interest rate fueled the accumulation of more debt through increase in interest payments and the consequent debt-deficit spiral.

The econometric results revealed that neither the long-term nor short-term interest rate is determined by fiscal deficit in India. This result has significant policy implications for interest rate determination in India, as the central bank has kept the policy rates unchanged in all recent policy announcements, citing prime reasons being the high fiscal deficits. Keeping the interest rates high or 
unchanged has negative implications for economic growth. While the central banks, globally, reduced the interest rates, only RBI of India deciding not to cut interest rates, as fiscal deficitwhich does not have any empirical evidence for determining both shorts and longs—is high in India. 


\section{REFERENCES}

Ahmad, M. 1994. "The Effects of Government Budget Deficits on Interest Rates: A Case Study of a Small Open Economy." Economia Internazionale 1(1): 1-6.

Baillie, R. T.1989. “Tests of Rational Expectations and Market Efficiency.” Econometric Reviews 8(2): 151-86.

Baillie, R., C. Chung, and M. Tieslau. 1996. "Analyzing Inflation by the Fractionally Integrated ARFIMA-GARCH Model.” Journal of Applied Econometrics 11(1): 23-40.

Balkan, E. M. and Erol, U. 1995. "Country Risk and International Portfolio Diversification." Economia Internazionale 48(1): 1-12.

Ball, L. and S. G. Cecchetti. 1990. "Inflation and Uncertainty at Long and Short Horizons." Brookings Papers on Economic Activity 1(1990): 215-45.

Barro, R. J. 1974. “Are Government Bonds Net Wealth?” Journal of Political Economy 82 (6): 1095-1117.

Blinder, A. and Solow, R. M. 1973. "Does Fiscal Policy Matter?” Journal of Public Economics 2(4): 319-37.

Buiter, W. 1990. Principles of Budgetary and Financial Policy. Cambridge, Mass: MIT Press.

Caines, P. E., C. W. Keng, and S. P. Sethi. 1981. "Causality Analysis and Multivariate Autoregressive Modeling with an Application to Supermarket Sales Analysis.” Journal of Economic Dynamics and Control 3(1): 267-98.

Carlson, A. J. 1977. "Short-Term Rates as Predictors of Inflation: Comment." American Economic Review 67(3): 469-75.

Cebula, R. J. 1990. “Government Borrowing and Interest Rates in United States: An Empirical Analysis Using IS-LM Framework.” Economia Internationale 43(2): 159-64.

—. 1997. “The Impact of Federal Budget Deficits on Long-Term Nominal Interest Rates in the US: New Evidence and an Updating Using Cointegration and Granger-Causality Tests, 1973.2-1993.3." Economia Internazionale 50(1): 49-60.

Chakraborty, L. 2002. "Fiscal Deficit and Rate of Interest: An Econometric Analysis of the Deregulated Financial Regime.” Economic and Political Weekly 37(19): 1831-38.

—. 2007. "Fiscal Deficit, Capital Formation, and Crowding Out in India: Evidence from an Asymmetric VAR Model.” Working Paper No. 518. Annandale-on-Hudson, NY: The Levy Economics Institute of Bard College.

Correia-Nunes, J. and Stemitsiotis, L. 1995. "Budget Deficit and Interest Rates: Is There a Link? International Evidence." Oxford Bulletin of Economics and Statistics 57(4): 425-49. 
Culver, S. E., and D. H. Papell. 1997. "Is There a Unit Root in the Inflation Rate? Evidence from Sequential Break and Panel Data Models." Journal of Applied Econometrics 12(4): 436-44.

Dalamagas, B. A. 1987. "Government Deficits, Crowding Out, and Inflation: Some International Evidence.” Public Finance 42(1): 65-84.

Elmendorf, D. W. and G. Mankiw. 1998. “Government Debt.” NBER Working Papers No. 6470. Cambridge, MA: National Bureau of Economic Research.

Evans, P. 1985. “Do Large Deficits Produce High Interest Rates?” American Economic Review 75(1): 68-87.

Fama, E. 1975. "Short-Term Rates as Predictors of Inflation." American Economic Review 65(3): 269-82.

Feldstein, M. 1976. "Inflation, Income Taxes, and Interest Rates: A Theoretical Analysis." American Economic Review 66(5): 809-20.

Fisher, I. 1930. The Theory of Interest. New York, NY: Macmillan.

Gale, W. G. and P. R. Orszag. 2002. "The Economic Effects of Long-Term Fiscal Discipline." Urban-Brookings Tax Policy Center Discussion Paper. Washington, DC: UrbanBrookings Tax Policy Center.

Gibson, W. E. 1970. “Price Expectations Effects on Interest Rates.” Journal of Finance 25(3): 1934.

Girton, L. and D. Nattress. 1985. "Monetary Innovations and Interest Rates.” Journal of Money, Credit, and Banking 17(3): 289-97.

Goyal, R. 2004. "Does Higher Fiscal Deficit Lead to Rise in Interest Rates?” Economic and Political Weekly 39(21): 2128-33.

Grier, K. B. 1986. “A Note on Unanticipated Money Growth and Interest Rate Surprises: Mishkin and Makin Revisited." Journal of Finance 41(4): 981-85.

Gupta, K. L. 1984. "Budget Deficits and Interest Rates in the United States." Public Choice 60: 87-92.

Gupta, K. L. 1992. Budget Deficits and Economic Activity in Asia. London, UK: Routledge.

Gupta, K. L. and B. Moazzami. 1996. Interest Rate and Budget Deficit: A Study of the Advanced Economies. London, UK: Routledge.

Hsiao, C. 1981. "Autoregressive Modeling and Money-Income Causality Detection.” Journal of Monetary Economics 7(1): 85-106. 
Johansen, S. 1992. "Determination of Co-Integration Rank in the Presence of a Linear Trend." Oxford Bulletin of Economics and Statistics 54(3): 383-97.

Kotlikoff, L. J. 1984. “Taxation and Saving: A Neoclassical Perspective." Journal of Economic Literature 22(4): 1576-1629.

Kulkarni, G. K. and E. L. Erickson. 1996. "Is Crowding Out Hypothesis Evident in LDCs?: A Case of India.” Indian Economic Journal 43(1): 116-26.

Levin, A. and C-F. Lin. 1992. "Unit Root Tests in Panel Data: Asymptotic and Finite-Sample Properties.” Discussion Paper 92-23. San Diego, California: University of California.

Lucas, R. E., Jr. 1980. “Two Illustrations of the Quantity Theory of Money.” American Economic Review 70(5): 1005-14.

Makin, J. 1983. "Real Interest, Money Surprises, Anticipated Inflation and Fiscal Deficits.” Review of Economics and Statistics 65(3): 374-84.

Mishkin 1982. "Does Anticipated Monetary Policy Matter? An Econometric Investigation." Journal of Political Economy 90(1): 22-51.

Nachane, D. M., A. V. Karnik, and N. R. Hatekar. 1997. "The Interest Rate Imbroglio: Monetary and Fiscal Dimensions." Economic and Political Weekly 32(20/21): 1167-74.

Nelson, C. R. and C. I. Plosser. 1982. "Trends and Random Walks in Macroeconomic Time Series: Some Evidence and Implications.” Journal of Monetary Economics 10(2): 13962.

Ostrosky, A. 1979. "An Empirical Analysis of the Crowding Out Effect of Fiscal Policy in the United States and Canada: Comments and Extensions." Kyklos 32(3): 497-522.

Parker, K. 1995. “The Behaviour of Private Investment.” IMF Occasional Paper No. 134 Washington, DC: International Monetary Fund.

Perron, P. 1989. "The Great Crash, the Oil Price Shock, and the Unit Root Hypothesis." Econometrica 57(6): 1361-1401.

Pradhan, B.K., D.K. Ratha, and A. Sarma. 1990. "Complementarity between Public and Private Investment in India.” Journal of Development Economics 33(1): 101-16.

Reserve Bank of India. 2002. Handbook of Statistics on the Indian Economy, 2001. Mumbai, India: Reserve Bank of India.

Samuelson, P. A. 1947. Foundations of Economic Analysis. Cambridge, MA: Harvard University Press.

Sargent, T. J. 1969. "Commodity Price Expectations and The Interest Rate." Quarterly Journal of Economics 83(1): 127-40. 
Shiller, R. J. 1979. "The Volatility of Long Term Interest Rates and Expectations Models of the Term Structure.” Journal of Political Economy 87(6): 1190-1219.

Sundararajan, V. and Thakur, S. 1980. "Public Investment, Crowding Out and Growth: A Dynamic Model Applied to India and Korea.” IMF Staff Papers. 27(4): 814-55.

Tanzi, V. 1985. "Fiscal Deficits and Interest Rates in the United States: An Empirical Analysis, IMF Staff Papers 32(4): 551-61.

Toda, H. Y. and T. Yamamoto. 1995. "Statistical Inference in Vector Autoregressions with Possibly Integrated Processes.” Journal of Econometrics 66(1-2): 225-50.

Vinod, H. 2006. "Maximum Entropy Ensembles for Time Series Inference in Economics." Journal of Asian Economics 17(6): 955-78.

Wood, J. H. 1981. "Interest Rates and Inflation.” Federal Reserve Bank of Chicago, Economic Perspectives 5(May/June) 3-12.

Zivot, E. and D. W. K. Andrews. 1992. "Further Evidence on the Great Crash, the Oil-Price Shock, and the Unit-Root Hypothesis." Journal of Business \& Economic Statistics, American Statistical Association 10(3): 251-70. 